The climbers must be absolutely fit and have had an opportunity of acclimatisation, undisturbed by any incident calling for great exertion on their part, such as having to rescue porters from dangerous positions. Yet such incidents are liable to occur.

The margin between success and failure must always be small-that is what makes it such a great adventure. Many favourable conditions must conspire to take the climbers to the summit ; without these, success is doubtful.

We have no information as to the plans of the new expedition but we fancy the same camps will be occupied up to, and including, Camp IV on the Chang La $(22,990 \mathrm{ft}$.) with, perhaps, some form of portable hut at Camp III as has been suggested. Higher up an attempt may probably be made to establish three camps in order to climb the remaining $6,000 \mathrm{ft}$.

As regards oxygen, since 1924 a much lighter form of apparatus has been constructed, weighing only about $12 \mathrm{lb} . *$ While a high degree of acclimatisation will be aimed at by the climbers selected for the final assault, no doubt the latest

- See Nature, 128, 1037, Dec. 19, 1931. form of light oxygen equipment will be provided, so that it can be used if required for the last portions of the ascent. Aptitude for acclimatisation appears to vary with the individual. With some persons, deterioration, due to remaining at high altitudes, may set in before acclimatisation has been fully attained; this has always to be reckoned with. We think, given reasonable luck, Everest will be climbed. If fortune smiles the summit will be reached.

The new expedition will be led by Mr. Hugh Ruttledge, formerly of the Indian Civil Service, who has had a great deal of Himalayan experience. The other members of the expedition are Mr. F. S. Smythe, leader of the successful Kamet expedition, with three of his companions-Capt. Burney, Dr. Raymond Green, and Mr. E. E. Shipton; Mr. Noel Odell, Mr. C. G. Crawford, Mr. Shebbear, members of former Everest expeditions; Messrs. Wyn Harris, J. Longland, G. Wood-Johnson, and Capt. Hugh Boustead, and possibly Dr. W. McLean as second doctor; Mr.L. R. Wager, of the Arctic Air Route Expedition, 1930-31, and Mr. T. Brocklebank.

\title{
Scientific Centenaries in 1933
}

By Eng.-Capt. Edgar C. Smith, o.B.E., R.N.

$\mathrm{T}$ HE year which has just closed saw the commemoration of the centenaries of many famous men, among whom were Scott, Goethe, Leeuwenhoek, Locke and Warren Hastings. Of especial interest to men of science was the commemoration of the tercentenary of Wren, while the celebration at Cologne of the centenary of Otto attracted considerable attention in the engineering world.

The closing month of the year also saw the commemoration of four other men distinguished as engineers or inventors. On December 7, the American Society of Mechanical Engineers at its annual dinner paid tribute to the memory of John Edson Sweet (1832-1916), a founder of the Society and once professor of engineering at Cornell, and to the memory of Alexander Lyman Holley (1832-1882), a singularly gifted man, whose monument in Washington Square, New York, describes him as "Foremost among those whose genius and energy established in America and improved throughout the world the manufacture of Bessemer steel". Eight days later, on December 15 , a ceremony took place at the base of the Eiffel Tower to commemorate the centenary of the birth of its constructor, Gustave Eiffel (1832-1923), while on December 23 various tributes were paid to the memory of Sir Richard Arkwright (1732-1792) who reduced to practice the principle of roller drawing in spinning machines, and was the founder of the factory system of cotton manufacture as we know it to-day. Lecky, the historian, speaking of the wealth which accrued to Great Britain through the cotton mill and the steam engine, and the power this wealth gave the country for carrying on the great French wars, declared that Arkwright and Watt deserved statues beside those of Wellington and Nelson, but so far no monument has ever been erected by his countrymen to Arkwright.

Earlier in the year, at Camborne, Prince George unveiled a statue of the Cornish engineer, Richard Trevithick, the centenary of whose death, falling on April 22 this year, will be commemorated by the engineering world on a scale in keeping with Trevithick's place as a pioneer. Trevithick died at Dartford, Kent, a poor man and for half a century was almost forgotten. The publication of his life by his son in 1872 did much to rescue his achievements from oblivion, and in 1888 a memorial window was erected to him in Westminster Abbey.

The forthcoming celebration is being supported by the leading engineering societies of Great Britain, and the arrangements are in the hands of a committee of which Sir Murdoch Macdonald is chairman. There will be memorial services in Dartford Parish Church and Westminster Abbey, an eminent engineer will deliver an address on Trevithick's work as an inventor, and the com. mittee hopes to be able to erect tablets to Trevithick at his birthplace, Illogan, Cornwall, and also at Pen-y-daren, South Wales, and near Euston Road, London, to record his early attempts to introduce steam locomotion on roads and railways. Trevithick's reputation has never stood higher than it does to-day. He may indeed be proclaimed the father of the high-pressure steam engine. 
Many other engineering centenaries also occur this year. A far less well-known inventor who died three months before Trevithick was Frederick König (1774-1833), whose four patents of 1810-14 led to the construction of the flat-bed printing press in which the paper was pressed against the type by a revolving cylinder. A red letter day in the history of printing was November 28, 1814, when the Times was first produced on a König machine driven by a steam engine.

Two centuries ago, on February 11, 1733, John Perry died at Spalding at the age of sixty-three years. For many years he was comptroller of maritime works under Peter the Great. He constructed harbour works in Great Britain and as the inscription on his tomb in Spalding Parish Church records, he was "Employed by ye Parliament to stop Dagenham Breach which he Effected and thereby Preserved the Navigation of the River of Thames and Rescued many Private Familys from Ruin".

Engineers born a hundred years ago include Sir Richard Tangye (1833-1906), the best known of the brothers who built up the great Cornwall Works at Birmingham; Thomas Edwards Vickers (1833-1915), another engineer and captain of industry of world-wide fame; James Robson (1833-1913), a pioneer of the gas engine; Henry Wilde (1833-1919), one of the leading inventors of the dynamo and Rudolph Haack (1833-1909) who at Stettin built the first ironclad constructed in Germany, and helped to lay the foundation of the German shipbuilding industry.

Turning to other fields of human endeavour, it is not necessary to stress the interest which is attached to the bicentenary of the birth of Joseph Priestley (1733-1804) who was born at Birstal, Leeds, and died at Northumberland, Pennsylvania. The statues of Priestley at Leeds, Birmingham and Oxford, testify to the esteem in which his memory has been held, and it may be recalled that it was at the celebration on August 1, 1874, of the centenary of his discovery of oxygen, on the piazza of his dwelling-house in Northumberland, that the American Chemical Society was founded, one of many instances of the value of such commemorations. Priestley was one of the few Englishmen elected a foreign associate of the Institute of France, the secretary of which, Cuvier, in his éloge, referred to him as "le père de chimie modèrne qui ne voulait pas reconnaître sa fille".

Among Priestley's intimate friends was the geologist and chemist, Richard Kirwan (17331812), who, like Priestley, received the Copley medal of the Royal Society. Kirwan was in correspondence with many of the leading savants of Europe, his London house was the meetingplace of the learned and after he returned to his native country, he became president of the Royal Irish Academy.

The year 1733 also saw the birth of Jean Charles Borda (1733-1799), the eminent French mathematician and astronomer; of Dr. Thomas
Hornsby (1733-1810), the successor of Bradley as Savilian professor of astronomy at Oxford and the first Radcliffe Observer, and of the famous German traveller, Carsten Niebuhr (1733-1815), the pupil and friend of the astronomer, Tobias Mayer.

Somewhat later than these eighteenth century worthies came Joseph Nicephore Niepce (17651833), the French chemist, whose statue at Chalons recalls his achievement of obtaining sun prints on metal plates ; Thomas Allan (1777-1833), the Edinburgh mineralogist; Adrien Marie Legendre (1752-1833), the French mathematician, writer of many works and the contemporary of Lagrange and Laplace. Legendre's "Elements of Geometry" was translated into English by Thomas Carlyle.

To the names of these three men who died in 1833 may be added that of Dr. William Babington (1756-1833), whose statue in St. Paul's Cathedral is regarded as a fine example of portraiture in marble. Babington was physician for many years to Guy's Hospital, and it was at his house that the meetings took place which led to the foundation of the Geological Society. Active to the last, when seventy-six years of age, he presided over the Priestley centenary festival on March 26, 1833 , but died of influenza three days later. He is buried in St. Mary Aldermanbury in the City.

Coming nearer our own times, it is but natural that with increase of opportunity, the lists of men who make notable contributions to discovery and progress should grow longer. "Life," said Emerson, "is girt round with a zodiac of sciences, the contributions of men who have perished to add their point of light to our sky. These road makers on every hand enrich us." To this everincreasing group of men belong many born in 1833, among them Sir Henry Roscoe (1833-1915); the German mathematician, Rudolph Clebsch (1833-1872); and the meteorologist, Robert Henry Scott (1833-1916), the successor of FitzRoy at the Meteorological Office. On April 15 was born Maurice Loewy (1833-1907), the constructor of the equatorial coudé and the successor of Tisserand as director of the Paris Observatory ; on May 5, Ferdinand, Baron von Richthofen (18331905), the geologist and geographer ; on March 16 , Hilary Bauerman (1833-1909), the metallurgist and benefactor of the Iron and Steel Institute and the Royal School of Mines; and on June 29, Peter Waage (1833-1900), the distinguished Norwegian chemist, student of Bunsen, successor of Strecker and collaborator with Guldberg.

Then, too, on October 15 and October 21, 1833, respectively, occurred the births of Frederick Guthrie (1833-1886), through whose efforts the Physical Society of London was founded, and of Alfred Bernhard Nobel (1833-1896), the Swedish engineer, chemist and inventor of explosives, by whose will of November 27, 1895, the bulk of his great fortune was used for founding the famous Nobel prizes for physics, chemistry, medicine, literature and peace. 